\title{
CCN activity of size-selected aerosol at a Pacific coastal location
}

\author{
J. D. Yakobi-Hancock ${ }^{1}$, L. A. Ladino ${ }^{1}$, A. K. Bertram ${ }^{2}$, J. A. Huffman ${ }^{3}$, K. Jones ${ }^{4}$, W. R. Leaitch ${ }^{5}$, R. H. Mason ${ }^{2}$, \\ C. L. Schiller ${ }^{4}$, D. Toom-Sauntry ${ }^{5}$, J. P. S. Wong ${ }^{1}$, and J. P. D. Abbatt ${ }^{1}$ \\ ${ }^{1}$ University of Toronto, Toronto, Ontario, Canada \\ ${ }^{2}$ University of British Columbia, Vancouver, British Columbia, Canada \\ ${ }^{3}$ University of Denver, Denver, Colorado, USA \\ ${ }^{4}$ Air Quality Science Unit, Environment Canada, Vancouver, British Columbia, Canada \\ ${ }^{5}$ Climate Research Division, Environment Canada, Toronto, Ontario, Canada
}

Correspondence to: J. D. Yakobi-Hancock (jyakobi@dal.ca)

Received: 22 April 2014 - Published in Atmos. Chem. Phys. Discuss.: 16 May 2014

Revised: 9 September 2014 - Accepted: 14 October 2014 - Published: 24 November 2014

\begin{abstract}
As one aspect of the NETwork on Climate and Aerosols: addressing key uncertainties in Remote Canadian Environments (NETCARE), measurements of the cloud condensation nucleation properties of 50 and $100 \mathrm{~nm}$ aerosol particles were conducted at Ucluelet on the west coast of Vancouver Island in August 2013. The overall hygroscopicity parameter of the aerosol $\left(\kappa_{\text {ambient }}\right)$ exhibited a wide variation, ranging from $0.14 \pm 0.05$ to $1.08 \pm 0.40$ (where the uncertainty represents the systematic error). The highest $\kappa$ values arose when the organic-to-sulfate ratio of the aerosol was lowest and when winds arrived from the west after transport through the marine boundary layer. The average $\kappa_{\text {ambient }}$ during this time was $0.57 \pm 0.16$, where the uncertainty represents the standard deviation. At most other times, the air was predominantly influenced by both marine and continental emissions, which had lower average $\mathrm{PM}_{1}$ $\kappa_{\text {ambient }}$ values (max value, $0.41 \pm 0.08$ ). The two-day average aerosol ionic composition also showed variation, but was consistently acidic and dominated by ammonium (18-56\% by mole) and sulfate (19-41\% by mole), with only minor levels of sodium or chloride. Average $\kappa_{\text {org }}$ (hygroscopicity parameter for the aerosol's organic component) values were estimated using $\mathrm{PM}_{1}$ aerosol composition data and by assuming that the ratio of aerosol organic to sulfate mass is related directly to the composition of the size-selected particles.
\end{abstract}

\section{Introduction}

Atmospheric aerosol particles directly affect the Earth's radiative budget by scattering and absorbing incoming solar radiation (Charlson et al., 1992). Additionally, these particles can indirectly influence the radiative budget of the Earth by acting as cloud condensation nuclei $(\mathrm{CCN})$ in the formation of warm clouds (Albrecht, 1989). Warm clouds can trap the Earth's outgoing infrared radiation, reflect incoming solar radiation, and influence the hydrological cycle and thus impact its climate (Albrecht, 1989; Twomey, 1977b). More specifically, warm clouds in marine regions are significant contributors to the Earth's radiative flux due to their extensive coverage and large albedo in relation to the ocean surface (Hartmann et al., 1992). It is well known that the indirect effects of these particles on climate constitute one of the largest uncertainties in understanding the present-day climate sensitivity (IPCC, 2013). This large degree of uncertainty arises partially from an incomplete understanding of aerosol particles' abilities to act as CCN. Consequently, because of the resulting sensitivity of the Earth's radiative budget to lowlying clouds, it is crucial to ensure that their $\mathrm{CCN}$ properties are well characterized.

Marine aerosol consists of two distinct sources: (1) primary sea-spray aerosol directly produced by breaking waves, consisting of inorganic salts and biogenic material such as surface-active microorganisms and exopolymer secretions; and (2) secondary aerosol formed by gas-to-particle conversion processes, mainly consisting of non-sea-salt (nss) sulfate and organic species (O'Dowd et al., 1997; Twomey, 1977a). 
However, in both coastal and marine locations it is also common for aerosol of anthropogenic and continental biogenic origin to be present, for instance, as a result of emissions by forests, populated areas, and shipping traffic. These sources can in turn result in high levels of substances of relevance to cloud formation, such as secondary organic aerosol (SOA) and sulfates, that are carried into the marine boundary layer by turbulence and convective mixing (Chang et al., 2010; Charlson et al., 1992; Coggon et al., 2012; Shantz et al., 2010).

While an enormous amount of effort has been applied to understanding and characterizing the aerosol hygroscopicity and CCN properties of continental biogenic, anthropogenic, and primary sea-spray aerosol (e.g. Andreae and Rosenfeld, 2008; Bigg, 2007; Chang et al., 2010; Coggon et al., 2012; Fuentes et al., 2011; Hegg et al., 2009; Kanakidou et al., 2005; Langley et al., 2010; Leck and Bigg, 2005a, b; Mei et al., 2013a, b; Moore et al., 2011; Orellana et al., 2011; Ovadnevaite et al., 2011; Prather et al., 2013; Roberts et al., 2006; Shantz et al., 2010; Sun and Ariya, 2006), this has not been the case for coastal or marine aerosol (herein referred to as coastal/marine aerosol) that has been influenced by marine organics. In particular, past studies have resulted in a wide range in the $\mathrm{CCN}$ properties of measured coastal/marine aerosol, making the direct comparison of results a challenge (Aalto and Kulmala, 2000; Allen et al., 2011; Ayers and Gras, 1991; Ayers et al., 1997; Bougiatioti et al., 2009; Good et al., 2010; Hegg et al., 1991; Hudson, 2007; Hudson et al., 2011; Kleinman et al., 2012; Lohmann and Leck, 2005; Meng et al., 2014; Moore et al., 2012; Ovadnevaite et al., 2011; Roberts et al., 2006, 2010; Shantz et al., 2008; Shinozuka et al., 2009; Sun and Ariya, 2006; Wang et al., 2008).

In addition to the poor characterization of ambient coastal/marine aerosol, only a handful of studies have estimated the CCN properties of organics in such a setting, which have been reported to possess similar $\mathrm{CCN}$ abilities to organics in continental regions (Bougiatioti et al., 2009; Cavalli et al., 2004; Martin et al., 2011; Matsumoto et al., 1997; Meng et al., 2014; Novakov and Penner, 1993). However, the CCN properties of marine organics have not been consistently reported using a standardized method, which makes the relative ranking of their water droplet formation abilities a challenge.

Determination of the effective hygroscopicity parameter, $\kappa$, has been identified as a simple method to describe aerosol $\mathrm{CCN}$ activities, where the $\kappa$ values of organic species of continental origin range from 0.02 to 0.2 , and those of inorganic species such as $\left(\mathrm{NH}_{4}\right)_{2} \mathrm{SO}_{4}$ and $\mathrm{NaCl}$ vary from 0.6 to 1.3 (Petters and Kreidenweis, 2007, and references therein). The $\mathrm{CCN}$ abilities of aerosol particles depend on both their sizes and compositional characteristics, such as water solubility and surface activity (Petters and Kreidenweis, 2007, 2013). By using this parameterization, these $\mathrm{CCN}$ abilities can be reported using a single standardized method.

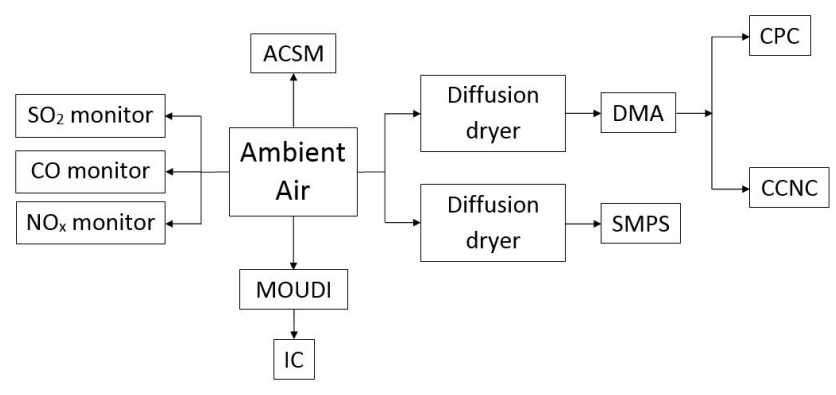

Figure 1. Schematic of the main components of the experimental set-up, which included $\mathrm{SO}_{2}, \mathrm{CO}$, and $\mathrm{NO}_{\mathrm{x}}$ monitors, an aerosol chemical speciation monitor (ACSM), micro-orifice uniform deposit impactor (MOUDI), ion chromatograph (IC), differential mobility analyser (DMA), condensation particle counter (CPC), cloud condensation nuclei counter (CCNC), and a scanning mobility particle sizer (SMPS). The ACSM, and $\mathrm{SO}_{2}, \mathrm{CO}$, and $\mathrm{NO}_{\mathrm{x}}$ monitors were in a neighbouring trailer.

In this study we use the hygroscopicity parameter approach to report the CCN activity of 50 and $100 \mathrm{~nm}$ ambient aerosol particles that were present on the west coast of Vancouver Island (Ucluelet, British Columbia) in August 2013. These experiments were conducted as part of a campaign to examine cloud formation properties of marine aerosol, as one component of the NETCARE (the NETwork on Climate and Aerosols: addressing key uncertainties in Remote Canadian Environments) project (http://www.netcare-project.ca/). This information is used in conjunction with the ambient aerosol's $\mathrm{PM}_{1}$ organic-to-sulfate ratio to provide one of the first estimates of the hygroscopicity parameter of organics contained within coastal ambient particles.

\section{Experimental method}

The field campaign took place in August 2013 at a coastal field site which was situated roughly $100 \mathrm{~m}$ from shore and $2 \mathrm{~km}$ from the small town of Ucluelet (population 1800) on Vancouver Island, BC, Canada $\left(48.92^{\circ} \mathrm{N}, 125.54^{\circ} \mathrm{W}\right)$, as shown in Supplement Fig. S1. The difference in low and high tide heights in this region ranged from 1.0 to $3.1 \mathrm{~m}$ throughout August. The available instrumentation (Fig. 1) allowed for measurements of CCN activity, particle size distributions, particulate ionic and organic compositions, and gas phase $\mathrm{SO}_{2}, \mathrm{CO}, \mathrm{NO}_{\mathrm{x}}$, as described below. All instruments sampled air through a main inlet in a trailer's roof, with intakes about $25.5 \mathrm{~m}$ above sea level. The main inlets were stainless steel tubes $\left(1 / 2^{\prime \prime} \mathrm{OD}\right)$, which were connected to the instruments' inlets by $1 / 4^{\prime \prime}$ OD stainless steel tubing.

The focus of this work is on data that were collected using a CCN counter (DMT 100), which was used to calculate the $\kappa$ of the ambient aerosol ( $\left.\kappa_{\text {ambient }}\right)$, with the assumption that the droplets' surface tensions were $0.072 \mathrm{~J} \mathrm{~m}^{-2}$ (Petters and Kreidenweis, 2007) and the trailer's temperature was con- 


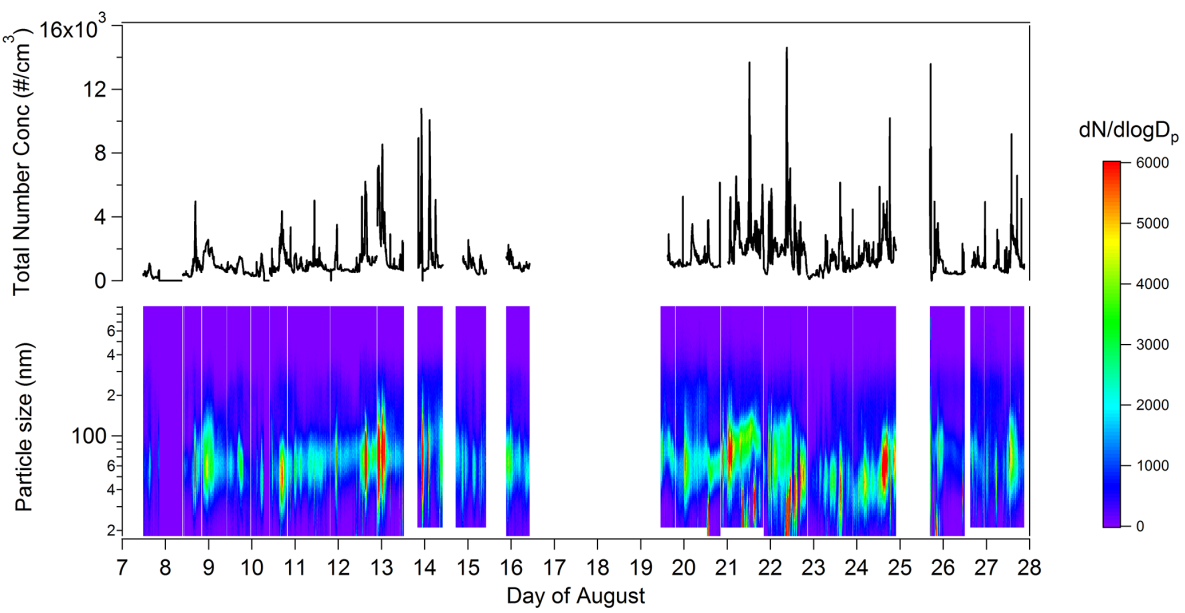

Figure 2. Time series (PDT) for 7-28 August of SMPS total number concentrations (top) particle size distribution (bottom). The colour bar indicates $\mathrm{d} N / \mathrm{d} \log D_{\mathrm{p}}$ in the bottom plot.

stantly $25^{\circ} \mathrm{C}$. Experiments were conducted from 7 to $23 \mathrm{Au}-$ gust on dry particles having mobility diameters of 50 and $100 \mathrm{~nm}$ that were size selected using a differential mobility analyser (DMA, TSI 3081), i.e. the DMA was fixed at one size during each experiment. Typical number concentrations for both sizes, after size selection, ranged from 2 to 20 particles $\mathrm{cm}^{-3}$. The silica gel in the diffusion dryers was exchanged and dried in an oven every $24 \mathrm{~h}$ in order to reduce the water content of the particles as much as possible. Although not measured on site in this campaign, we have found that this technique always reduces the relative humidity to less than $20 \%$, and usually to less than $2 \%$ (Ladino et al., 2014).

After size selection, the particle flow was split for measurement by the $\mathrm{CCN}$ counter as well as a Condensation Particle Counter (CPC, TSI 3010), which was used to measure the aerosol number concentrations. The number concentrations measured by the $\mathrm{CCN}$ and $\mathrm{CPC}\left(N_{\mathrm{CCN}}\right.$ and $N_{\mathrm{CPC}}$, respectively) were used to calculate the activated fraction, $\mathrm{AF}$ $=N_{\mathrm{CCN}} / N_{\mathrm{CPC}}$, examples of which are shown in Fig. S2 of the Supplement. Note that if the activated fraction's plateau was lower than 0.65 the scan was not used as the air was likely significantly polluted, and the focus of this work was on the marine component of the aerosol. It is possible that low plateaus arise from an externally mixed population of low-hygroscopicity carbonaceous particles from nearby marine pollution sources, but we have no direct evidence this is the case. The CCN counter was calibrated twice during the campaign using ammonium sulfate according to the procedure of Rose et al. (2008). Experiments consisted of increasing supersaturations in a step-wise manner from 0.07 to $1.2 \%$, where each supersaturation was held steady for 10 to $15 \mathrm{~min}$, and resulted in an experimental time resolution of 1.5 to $2 \mathrm{~h}$ for a full scan. As the CCN sampled directly from the output of the DMA, multiply charged particles were not avoided. However, the effect of multiply charged particles on the results (i.e. $\kappa_{\text {ambient }}$ ) was investigated according to a method summarized in Rose et al. (2008). It was found that the effect was insignificant, and so the uncorrected $\kappa_{\text {ambient }}$ values have been reported.

A scanning mobility particle sizer (SMPS, TSI 3081, 3782) measured dry aerosol size distributions of mobility diameters within the range of $19-914 \mathrm{~nm}$ every 2 minutes from 9 to 25 August, with some interruptions (Figs. 2 and 3 , top) due to instrument maintenance. A $0.071 \mathrm{~cm}$ diameter impactor was attached to the inlet of the SMPS, which sampled from the same main inlet as the CCN counter and CPC.

A micro-orifice uniform deposition impactor (MOUDI, MSP 110R) sampled directly from a separate main inlet, with a sample flow of $24 \mathrm{~L} \mathrm{~min}^{-1}$, to collect ambient particles that had not been dried (i.e. wet aerosol particles) in five size bins corresponding to aerodynamic diameters of 56-100, $100-180,180-320,320-560 \mathrm{~nm}$, and $560 \mathrm{~nm}-18 \mu \mathrm{m}$, where the bounds represent $50 \%$ cut-off efficiencies at $50 \%$ relative humidity (RH). In order to obtain sufficient particle mass for ion chromatography (IC) to be conducted on the particles, the MOUDI sampled for 2-day time periods (starting at local noon) from 13 to 25 August. Cationic and anionic chromatography was conducted on the collected particles in order to obtain the size-resolved 2-day average concentrations of $\mathrm{Na}^{+}, \mathrm{K}^{+}, \mathrm{NH}_{4}^{+}, \mathrm{Cl}^{-}, \mathrm{SO}_{4}^{2-}, \mathrm{NO}_{3}^{-}, \mathrm{NO}_{2}^{-}, \mathrm{C}_{2} \mathrm{O}_{4}^{2-}$ and methanesulfonic acid (MSA) (Phinney et al., 2006). Data from the two smallest size ranges (aerodynamic diameters 56-100 and $100-180 \mathrm{~nm}$; i.e. mobility diameters $42-75$ and $78-141 \mathrm{~nm}$, respectively) will be discussed here. The derivation of the particles' mobility diameters from their aerodynamic diameters can be found in Sect. S1 of the Supplement. The uncertainty in the ionic concentrations is estimated to be $\pm 20 \%$ based on the MOUDI's collection efficiency, sample handling procedures and analytical methods. The tempera- 


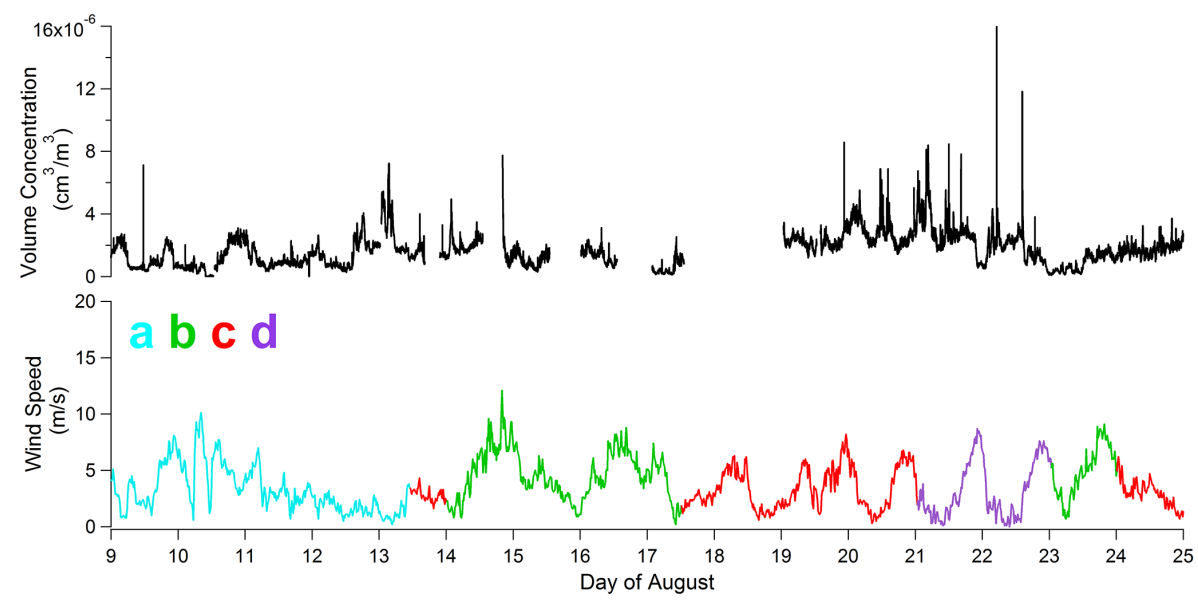

Figure 3. Time series (PDT) for 9-25 August of SMPS total volumetric concentrations (top) and wind speed (bottom). The wind's direction is classified as type a, b, c and d, according to the air mass classification scheme described in Sect. 3.1.

ture and relative humidity in the trailer containing the $\mathrm{CCN}$, SMPS, and MOUDI setups were monitored for the duration of the campaign (Acurite 00891W3). The temperature was found to range from 21 to $30^{\circ} \mathrm{C}$ (mean value of $25^{\circ} \mathrm{C}$ ), and the relative humidity varied from 28 to $58 \%$ (mean value of $45 \%$ ) from 7 to 23 August.

An aerosol chemical speciation monitor (ACSM, Aerodyne, $\mathrm{Ng}$ et al., 2011) was located in a second trailer $14 \mathrm{~m}$ from the primary trailer, and sampled from its own main inlet. The trailer's temperature was controlled at $22^{\circ} \mathrm{C}$. The ACSM measured the total organic, $\mathrm{SO}_{4}^{2-}$ and $\mathrm{NO}_{3}^{-}$mass concentrations of particles having wet aerodynamic diameters smaller than $1 \mu \mathrm{m}$ every 25 min from 13 to 31 August, with a collection efficiency of $50 \%(\mathrm{Ng}$ et al., 2011). The ACSM was calibrated according to the Aerodyne procedure, using $\mathrm{NH}_{3} \mathrm{NO}_{3}$ aerosol that was generated from an aerosol generator (TSI 3076), a DMA (TSI 3081) to size select the particles, and a CPC (TSI 3772) to count the particles, and the data were corrected using the air beam. $\mathrm{SO}_{2}$ (Thermo 42i), $\mathrm{NO}_{\mathrm{x}}$ (Teledyne API 100TU) and $\mathrm{CO}$ (Thermo 48i-TL) monitors were also located in this trailer, where they shared a common inlet and sampled once a minute.

\section{Results and discussion}

\subsection{Air mass characteristics and origins}

The NOAA Air Resources Laboratory HYSPLIT model was used to generate $72 \mathrm{~h}$ back trajectories. To indicate their diversity, back trajectories are shown for 12:00 (Pacific Daylight Savings Time, PDT) on each day of the study as Fig. S1. Throughout the campaign, these trajectories indicate that air reaching the sampling site (red star) was the result of onshore winds and was within the marine boundary layer (below $\sim 1000 \mathrm{~m}$ ) for significant periods of time prior to sam- pling (see Supplement, Fig. S4 middle). During the entire campaign there were four types of air masses that arrived in Ucluelet: (a) air that was influenced by both marine and continental sources (trajectories that arrive from the north having travelled along the west coast of Vancouver Island and the BC mainland), (b) descending, non-boundary layer air from the west, (c) air predominantly from the west that was clearly from the marine boundary layer without continental influence, and (d) air that was within the marine boundary layer, originated from the west (i.e. Pacific Ocean), and spent time over Vancouver Island. Consequently, while the winds were typically on-shore, they most likely carried a mixture of anthropogenic (especially marine shipping), biogenic continental, and marine aerosol, as was expected due to the sampling site's coastal location.

A characteristic clean marine ratio of MSA to nss- $\mathrm{SO}_{4}^{2-}$ varies from 0.07 to 0.4 , depending on the study (Bates et al., 1992; Castebrunet et al., 2009; Chen et al., 2012; Norman et al., 1999; Phinney et al., 2006; Savoie and Prospero, 1989; Savoie et al., 2002). Because the measured 2-day average ratios of the entire MOUDI size range (all particles greater than $56 \mathrm{~nm}$ ), as calculated using the IC concentrations, range from $0.09 \pm 30$ to $0.16 \pm 30 \%$ (where the uncertainty represents the relative systematic error), there is evidence that the aerosol particles associated with the air masses contain a strong marine component. During the 2-day time periods that included periods of clean marine air (i.e. 17-19 and 19-21 August) the ratios of MSA to nss- $\mathrm{SO}_{4}^{2-}$ were 0.15 and 0.16 , respectively. For reference, according to Savoie and Prospero (1989), who reported a characteristic marine ratio of 0.07 , the aerosol would be classified as marine; however, according to Norman et al. (1999), who reported a characteristic marine ratio of 0.4 , the aerosol would have some anthropogenic contribution. Because this ratio varies considerably with sea surface temperature, particle size, season and latitude, there 


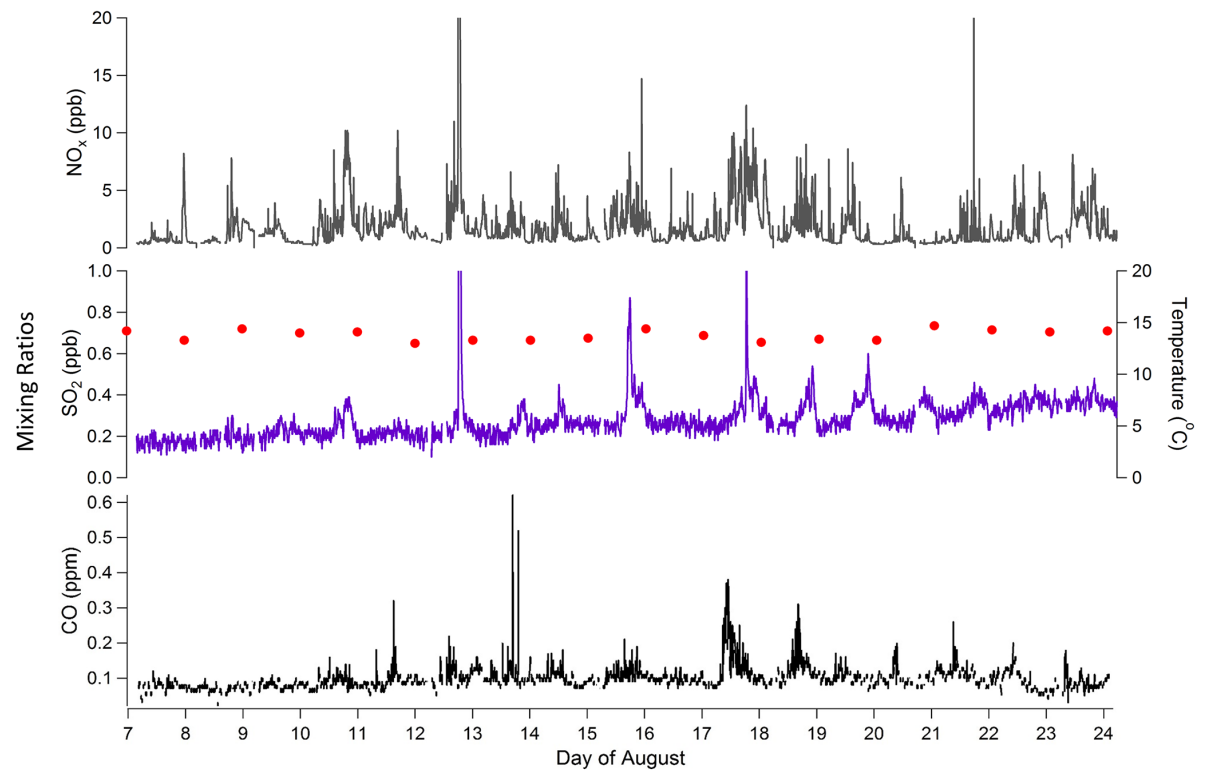

Figure 4. Time series (PDT) for 7-24 August of sea surface temperature (red circles), $\mathrm{NO}_{\mathrm{x}}$ (top), $\mathrm{SO}_{2}$ (middle) and $\mathrm{CO}$ (bottom) mixing ratios.

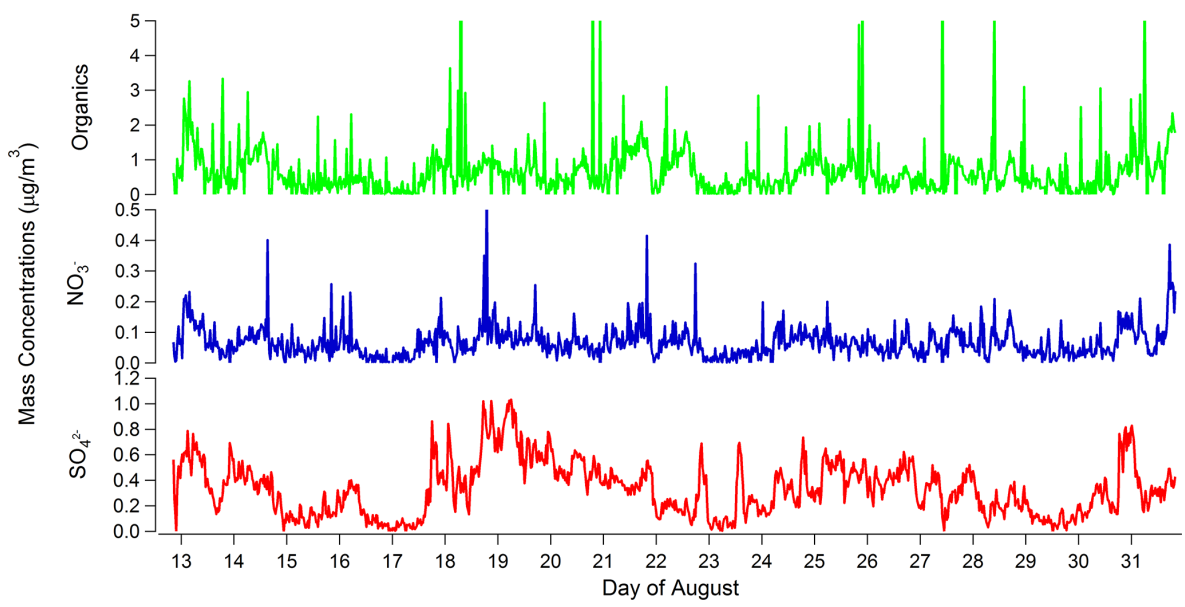

Figure 5. Time series (PDT) for 13-31 August of ACSM organics (green), $\mathrm{NO}_{3}^{-}$(blue) and $\mathrm{SO}_{4}^{2-}$ (red). The maximum organic mass concentrations are $8 \mu \mathrm{g} \mathrm{m}^{-3}$; however, the axis only reaches $5 \mu \mathrm{g} \mathrm{m}^{-3}$ for clarity.

is a not a single value of this ratio which identifies it with only pure marine air masses (Kerminen et al., 1998).

Figure 4 shows a time series (PDT) of the daily sea-surface temperature, $\mathrm{SO}_{2}$ and $\mathrm{NO}_{\mathrm{x}}$ mixing ratios, and $\mathrm{CO}$ mixing ratios. Based on the presence of $\mathrm{NO}_{\mathrm{x}}, \mathrm{SO}_{2}$ and $\mathrm{CO}$, it is clear that the air masses were anthropogenically influenced at times. These three species tended to increase between 11 a.m. and 11 p.m. on most days, with the maximum mixing ratios occurring between 5 and 8 p.m. (e.g. 12 and 15 August). As a result, in the cases when the air masses were of type (c), i.e. western, within the boundary layer, and of marine origin (see Fig. S1), it is likely that these signals arise from boat traffic (e.g. whale watching, fishing, pleasure, and sight-seeing boats). The maximum mixing ratios, which occurred in the late afternoon, were possibly due to these vessels entering the harbour ( $3.5 \mathrm{~km}$ from the sampling site) and docking for the night.

The average sulfate mass concentration as measured by the ACSM (Fig. 5) was quite low, $0.68 \pm 0.47 \mu \mathrm{g} \mathrm{m}^{-3}$, where the uncertainty represents the measurement's standard deviation, with the majority (54-87\%) estimated to be nss$\mathrm{SO}_{4}^{2-}$ based on the levels of sodium measured by ion chromatography (Warneck, 1988). The $\mathrm{NO}_{3}^{-}$levels as measured by the ACSM (Fig. 5) were typically very low in relation to the sulfate and organic mass concentrations, having an average mass concentration of $0.13 \pm 0.11 \mu \mathrm{g} \mathrm{m}^{-3}$. Figure 3 (top) 


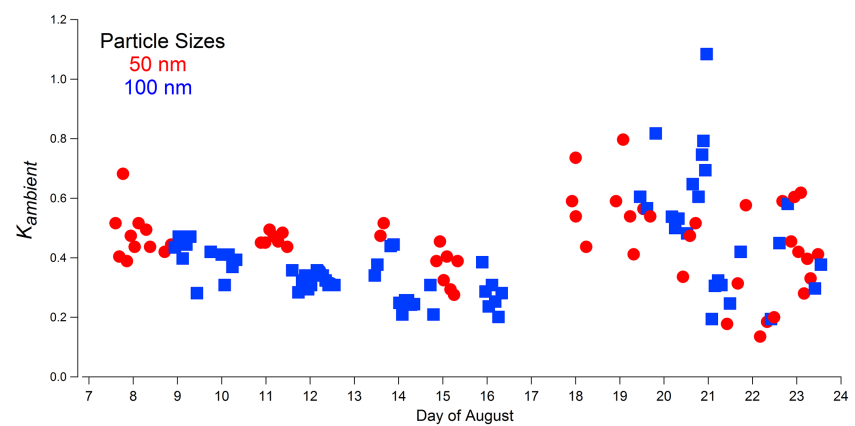

Figure 6. Time series (PDT) for 7-24 August of CCN-derived $\kappa_{\text {ambient }}$ of monodispersed ambient aerosol having dry mobility diameters of $50 \mathrm{~nm}$ (red circles) and $100 \mathrm{~nm}$ (blue squares). The relative error in $\kappa_{\text {ambient }}$ is $\pm 37 \%$.

shows the total particulate volume concentrations from 9 to 25 August as measured by the SMPS, which correlate reasonably well with the total mass concentration measured by the ACSM (having an $R^{2}$ value of 0.3 ). Figure 3 (bottom) illustrates the wind speed from 9 to 25 August, colour coded according to the corresponding air mass types. For the majority of August there was a clear diurnal trend in wind speed and power (i.e. wind speed cubed, not shown), with mid-day winds weaker than those occurring later in the day and into the night. Although this could be expected to cause a corresponding trend in the particle mass loadings if there is a large primary source, there was not a clear correlation between wind speed, wind speed cubed, or either the total number concentrations or total particulate volume concentrations shown in Fig. 2 (top) and Fig. 3 (top), respectively.

\subsection{Determining the hygroscopicity of the ambient aerosol $\left(\kappa_{\text {ambient }}\right)$ and its organic component $\left(\kappa_{\text {org }}\right)$}

The experimentally determined supersaturation required for $50 \%$ of the ambient particles to be activated as CCN $\left(S_{c}\right)$ is used to calculate $\kappa_{\text {ambient }}$ for 50 and $100 \mathrm{~nm}$ particles using Eq. (1), according to Petters and Kreidenweis (2007):

$$
\begin{aligned}
& \kappa_{\text {ambient }}=\frac{4 A^{3}}{27 D_{\mathrm{d}}^{3} \ln ^{2} S_{c}} \\
& A=\frac{4 \sigma_{\mathrm{s} / \mathrm{a}} M_{\mathrm{w}}}{R T \rho_{\mathrm{w}}},
\end{aligned}
$$

where $D_{\mathrm{d}}$ is the dry particle's mobility diameter, $\sigma_{\mathrm{s} / \mathrm{a}}$ is the surface tension of the solution/air interface (where the solution is assumed to be water at $25^{\circ} \mathrm{C}$ ), $M_{\mathrm{w}}$ is the molecular weight of water, $R$ is the gas constant, $T$ is the temperature and $\rho_{\mathrm{w}}$ is the density of water. Based on the uncertainties in quantities such as the particle size $( \pm 10 \%)$, temperature $\left( \pm 10^{\circ} \mathrm{C}\right)$, and instrumental and calibrated critical supersaturations $( \pm 10 \%)$, the relative error in $\kappa_{\text {ambient }}$ is calculated to be $\pm 37 \%$ through error propagation.
As shown in Fig. 6, the time series of $\kappa_{\text {ambient }}$ exhibits a large variability, ranging from 0.14 to 1.08 . Because previous studies have indicated a size dependency of the chemical composition of aerosol particles, it was expected that $\kappa_{\text {ambient }}$ may differ between the 50 and $100 \mathrm{~nm}$ particles (Andreae and Rosenfeld, 2008). However, the difference was found to be statistically insignificant, suggesting that the chemical composition of the two particle sizes was not significantly different. In addition, it should be noted that because the activation curves (examples of which are shown in the Supplement as Fig. S2) were generally characterized by stable plateaus and clear sigmoidal shapes, it was assumed that the CCN-active aerosol was chemically consistent and internally mixed during each experiment. However, there was evidence that the aerosol as a whole was externally mixed, containing both soluble and insoluble components, because the activated fractions' plateaus did not often reach 1 .

Through the use of the air mass classification scheme described in Sect. 3.1, four periods of air masses and $\kappa_{\text {ambient }}$ values are identified. First, an initial period where the trajectories were likely to be influenced by both marine and continental sources (i.e. air mass type (a), 7-12 August, representing trajectories that arrive from the north having travelled along the west coast of Vancouver Island and the BC mainland); second, an intermediate period of descending, nonboundary layer air from the west (i.e. air mass type (b), 14-16 and 23 August); third, a period of air that was clearly from the marine boundary layer to the west without continental influence (i.e. air mass type (c), 13 and 18-20 August); and finally, a period of air that was within the marine boundary layer, originated from the west (i.e. Pacific Ocean), and spent time over Vancouver Island (i.e. air mass type (d), 21-22 August).

Using this air mass classification, the highest $\kappa_{\text {ambient }}$ values, and most hygroscopic particles (18-21 August), are identified as being associated with the marine boundary layer air without continental influence (air mass type c). In contrast, air masses that were not necessarily only of marine origin (e.g. influenced by the continent or descended from above the marine boundary layer) were associated with lower $\kappa_{\text {ambient }}$ values. When the $\kappa_{\text {ambient }}$ values during each of the four air mass time periods were averaged, it was found that the average $\kappa_{\text {ambient }}$ values for both 50 and $100 \mathrm{~nm}$ particles were $0.41 \pm 0.08,0.33 \pm 0.10,0.57 \pm 0.16$, and $0.35 \pm 0.16$, during air mass types a, b, c, and d, respectively, where the uncertainties represent standard deviations.

The large range of $\kappa_{\text {ambient }}$ values is comparable to measurements described in the handful of other studies that have reported the hygroscopicity parameters of ambient marine aerosol. For instance, Shantz et al. (2008) presented a case study in which CCN measurements conducted on an oceanographic vessel in the North Pacific Ocean were used to calculate an average $\kappa$ range of 0.35 to 0.7 . Shinozuka et al. (2009) assessed the CCN activity of ambient aerosol during an aircraft campaign over the west coast of the USA using the 
DMT CCN counter. It was reported that $\kappa_{\text {ambient }}$ varied from 0.07 to 1.15 , where the value decreased with increasing organic mass fractions. During a cruise in the tropical Atlantic, Good et al. (2010) reported that the $\kappa$ of marine aerosol particles was between 1.15 and 1.40 . This range was in contrast to the lower $\kappa$ measured in more continental air masses, which varied from 0.75 to 0.89 . Roberts et al. (2010) reported a $\kappa$ of 0.21 in the northeastern Pacific marine boundary layer from an aircraft platform. This low value was attributed to the presence of a range of sources, including marine emissions, shipping emissions, long-range particle transport, and the downward mixing of particles from the free troposphere. CCN measurements were conducted with a DMT CCN counter by Moore et al. (2012) during flights over the eastern Pacific Ocean off the southern Californian coast, where the range of continentally influenced marine/coastal $\kappa$ values was reported to be $0.15-0.2$, which agreed well with the $\kappa$ of organic compounds reported by other studies (Petters and Kreidenweis, 2007). In addition, by conducting size-resolved CCN measurements at a coastal site in Hong Kong, Meng et al. (2014) determined that $\kappa_{\text {ambient }}$ was $0.39,0.31$ and 0.28 for 116,56 and $46 \mathrm{~nm}$ particles, respectively. The decrease in $\kappa_{\text {ambient }}$ was attributed to increasing organic to inorganic volume ratios as particle size decreased.

To interpret our observations, it is valuable to consider the composition of the particles in the size range that typically activate as CCN. In particular, according to Fig. 7, the ionic composition of $42-75$ and $78-141 \mathrm{~nm}$ particles was dominated by $\mathrm{NH}_{4}^{+}\left(18-56 \%\right.$ by mole) and $\mathrm{SO}_{4}^{2-}(19-41 \%$ by mole), and not by $\mathrm{Na}^{+}(2.5-23 \%$ by mole), indicating that the aerosol was largely not composed of $\mathrm{NaCl}$ (i.e. sea salt). In addition, because the majority (68-98 \% by mole) of $\mathrm{SO}_{4}^{2-}$ was present as nss- $\mathrm{SO}_{4}^{2-}$, the aerosol was likely secondary in nature, which highlights the potential importance of chemical processing when considering aerosol composition and origins. Furthermore, because a relationship was not found between $\kappa_{\text {ambient }}$ and wind speed (Fig. 3, bottom and Supplement, Fig. S4 bottom) (having an $R^{2}$ value of 0.01 ) or $\kappa_{\text {ambient }}$ and wind power (not shown), it is likely that the aerosol was more secondary in nature since primary marine aerosol emissions have been reported to correlate with wind speeds (O'Dowd et al., 1997). In general, the winds were low during the study, with little wave activity.

The observation that sulfate species dominate the composition of particles of the size ranges considered in this study agrees well with previous studies of the chemical composition of marine aerosol (Good et al., 2010; Hawkins et al., 2008; Moore et al., 2012; O’Dowd et al., 2004; Phinney et al., 2006; Prather et al., 2013). We note that the molar ratio of $\mathrm{NH}_{4}^{+}$to $\mathrm{SO}_{4}^{2-}$ is consistently between 1 and 2, indicating an acidic aerosol, likely formed by secondary processes associated with dimethyl sulfide (DMS) or $\mathrm{SO}_{2}$ oxidation, leading ultimately to the formation of MSA and $\mathrm{H}_{2} \mathrm{SO}_{4}$, and with insufficient ambient ammonia to provide full neutralization.

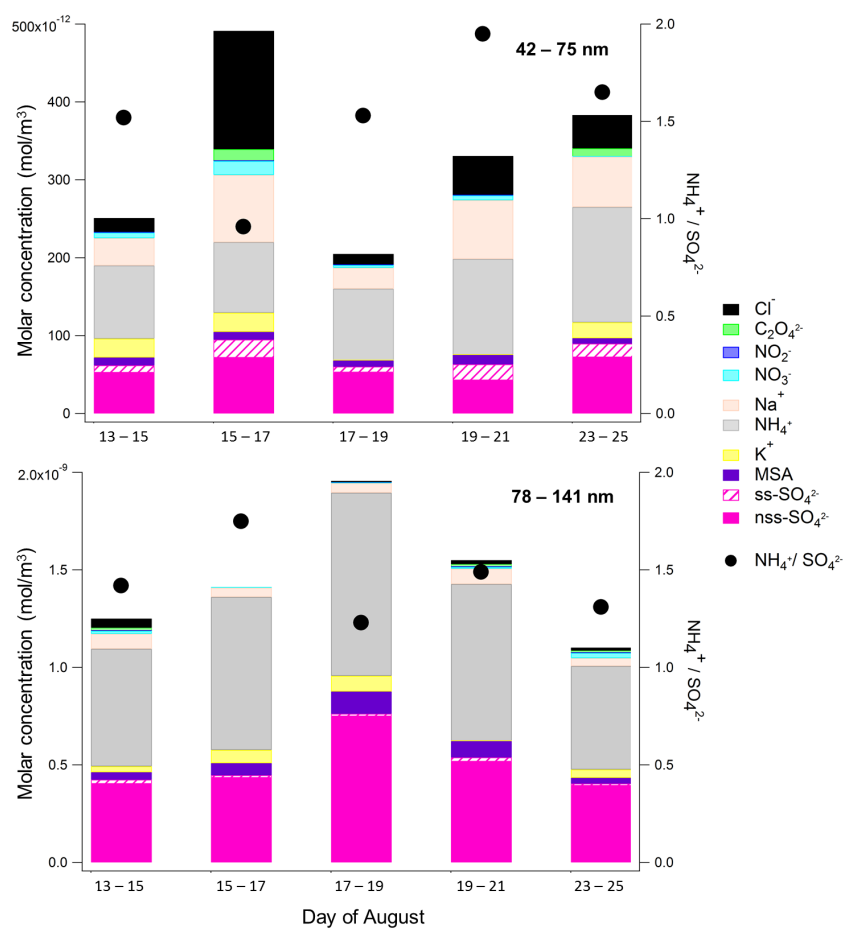

Figure 7. Average 2-day molar concentrations of ionic species present in $48-75 \mathrm{~nm}$ (top) and $78-141 \mathrm{~nm}$ (bottom) particles, as measured by the MOUDI/IC. The black circles represent the corresponding $\mathrm{NH}_{4}^{+}$to $\mathrm{SO}_{4}^{2-}$ molar ratios. Uncertainties in the ionic species' concentrations are $\pm 20 \%$. The 2-day sampling period starts at noon (PDT) on the first day indicated.

Finally, the relationships between $\kappa_{\text {ambient }}$ and the mixing ratios of $\mathrm{SO}_{2}, \mathrm{NO}_{\mathrm{x}}$, and $\mathrm{CO}$ were investigated using Fig. S3 of the Supplement; however, no correlations were found. This is likely because the pollutants were added to the air mass very close to the shore due to the marine traffic (see above), without time to lead to significant secondary aerosol modification.

By inspection of Fig. 8 (bottom), where $\kappa_{\text {ambient }}$ is considered as a function of the ACSM's $\mathrm{PM}_{1}$ organic to $\mathrm{SO}_{4}^{2-}$ ratio from 13 to 23 August, it is observed that some of the variability in the $\kappa_{\text {ambient }}$ data may be explained through the relationship between $\kappa_{\text {ambient }}$ and the $\mathrm{PM}_{1}$ organic to $\mathrm{SO}_{4}^{2-}$ ratio of the aerosol, where increasing $\mathrm{SO}_{4}^{2-}$ in relation to organics resulted in increasing $\kappa_{\text {ambient }}$ values. The particular dependence of the CCN activity of coastal and marine aerosol on sulfate content is supported by previous studies that partially attributed the $\mathrm{CCN}$ properties of marine aerosol to the presence of this species (Andreae and Rosenfeld, 2008; Matsumoto et al., 1997; Quinn and Bates, 2011, and references therein).

We note, as well, that there is a relationship between $\kappa_{\text {ambient }}$ and the average frequency of cloud coverage in the area. Through qualitative field-site observations that were conducted several times a day, it was found that complete 


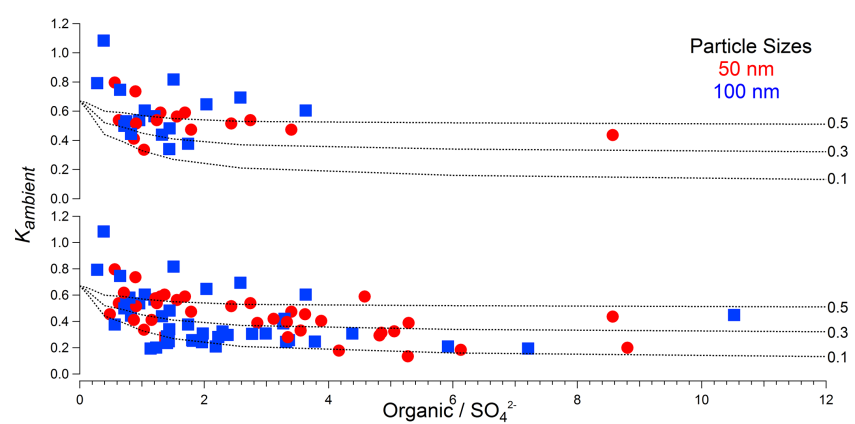

Figure 8. CCN-derived $\kappa_{\text {ambient }}$ of monodisperse ambient marine aerosol having dry mobility diameters of $50 \mathrm{~nm}$ (red circles) and $100 \mathrm{~nm}$ (blue squares) as a function of the organic to sulfate ratio measured by the ACSM from 13 and 18 to 20 August (top) and 13 to 23 August (bottom), PDT. Dotted black lines indicate calculated values of $\kappa_{\text {ambient }}$ from an assumed value for $\kappa_{\text {org }}$ (indicated at the right end of each line) and degree of sulfate neutralization taken from the MOUDI data.

cloud coverage was present approximately $67 \%$ of the time from 7 to 17 and 21 to 23 August, and only $35 \%$ of the time from August 18 to 20. While this correlation may simply be due to different cloud coverage being associated with different air mass types, the high $\kappa_{\text {ambient }}$ values that occurred from 18 to 20 August may also be due to the enhancement of biological processes such as the production of DMS by phytoplankton (Ayers and Cainey, 2007). The presence of sunlight would then have enhanced the photo-oxidation of DMS to $\mathrm{SO}_{4}^{2-}$, the levels of which were particularly high during this time period as shown in Fig. 5, whereas the organic mass loadings were not so affected. Because acidic sulfate has high kappa values (e.g. 0.90 for sulfuric acid), it is likely that the relatively sunny time period (18 to 20 August) led to the aerosol's $\kappa_{\text {ambient }}$ values to be driven up to values exceeding 0.7 .

The asymptotic value of Fig. 8 (bottom) at high values of organic to $\mathrm{SO}_{4}^{2-}$ ratios implies that the $\kappa$ value of the organics within the particles $\left(\kappa_{\text {org }}\right)$ was $0.3 \pm 0.2$ when data collected during air mass types b, c, and d are considered (i.e. 13-23 August). In particular, superimposed on Fig. 8 are lines that predict the overall $\kappa$ value from an assumed value for $\kappa_{\text {org }}$ and literature values for sulfate $\kappa$, where the overall sulfate is assumed to be a mixture of ammonium sulfate and sulfuric acid, with the relative amounts set by the MOUDI data. Interestingly, when data collected only during the periods of clean marine air are considered (i.e. air mass type $\mathrm{c}$ during 13, 18-20 August) in Fig. 8 (top), the asymptotic value suggests a somewhat larger $\kappa_{\text {org }}$. However, this is quite uncertain because there are not many data points at high organicto-sulfate ratios, which best constrain the value of $\kappa_{\text {org }}$. We stress that, because the ACSM is sensitive to $\mathrm{PM}_{1}$, with an upper size range close to $1 \mu \mathrm{m}$, i.e. much larger than the size of $\mathrm{CCN}$, this can only be viewed as a rough estimation of $\kappa_{\text {org }}$, with the assumption that the chemical compositions of $\mathrm{PM}_{1}$, and 50 and $100 \mathrm{~nm}$ particles are similar to one another.

A few previous studies have inferred values for $\kappa_{\text {org }}$ in marine/coastal settings. For instance, using $\mathrm{CCN}$ measurements taken at a remote marine site in the eastern Mediterranean, Bougiatioti et al. (2009) carried out a closure study in which a comparison was made between the predicted total $\mathrm{CCN}$ concentrations according to Köhler Theory and the measured concentrations. By assuming an organic density, molar mass and van't Hoff factor for the aerosol's organic fraction, $\kappa_{\mathrm{org}}$ was found to be about 0.16 , which is within the range of hygroscopicity parameters for highly aged or oxidized organic material (0.02-0.2) (Petters and Kreidenweis, 2007). This in turn resulted in an overall aerosol $\kappa$ of about 0.3 . Similarly, Martin et al. (2011) conducted a CCN closure study on summer high Arctic aerosol, based on measurements that were conducted during the Arctic Summer Cloud Ocean Study. $\mathrm{CCN}$ concentrations were predicted using Köhler Theory and various permutations of the relevant variables (hygroscopicity parameters of organics and sulfate, density of organics, fraction of water insoluble organics). By comparing the predicted and measured concentrations $\kappa_{\text {org }}$ was found to have a value of about 0.02 with an upper limit of 0.2 , which resulted in an overall mean aerosol $\kappa$ of 0.33 to 0.50 . As was the case for Bougiatioti et al. (2009), this range in $\kappa_{\text {org }}$ was comparable to the hygroscopicity parameters of oxidized organic material of continental origin (e.g. Dusek et al., 2010; Lathem et al., 2013; Petters and Kreidenweis, 2007; Shantz et al., 2008).

\section{Summary and conclusions}

A cloud condensation nucleus counter was used to investigate the CCN activity of ambient aerosol particles on the west coast of Canada (Ucluelet, BC) in August 2013 as one aspect of NETCARE. These results were used in conjunction with the ambient aerosol's 2-day average size-resolved ionic composition as well as $\mathrm{PM}_{1}$ organic-to-sulfate ratios to assess the role of organics and sulfate in promoting $\mathrm{CCN}$ behaviour in a marine environment. Trajectory analysis and the presence of MSA in the particles are indicative of a significant marine origin to the air masses studied.

The hygroscopicity parameter of the ambient marine aerosol exhibits a large degree of variability, ranging from $0.14 \pm 0.05$ to $1.08 \pm 0.40$, where the highest values arise when the organic-to-sulfate ratio of the aerosol is lowest and when the air is clearly marine boundary layer in origin. The 2-day average aerosol ionic composition in the 50 to $100 \mathrm{~nm}$ size range was consistently primarily composed of ammonium and sulfate species. The dominant presence of secondary ionic components such as nss- $\mathrm{SO}_{4}^{2-}(13-39 \%)$, and the low concentrations of $\mathrm{Na}^{+}$(a tracer for sea salt), highlights the importance of these secondary species in general, in addition to the primary components that have been re- 
ported to be drivers of the $\mathrm{CCN}$ properties of marine aerosol by previous studies (e.g. Andreae and Rosenfeld, 2008).

The $\mathrm{PM}_{1}$ organic-to-sulfate ratio and overall aerosol hygroscopicity was used to estimate the average hygroscopicity parameter of the organic species contained within the aerosol $\left(\kappa_{\text {org }}\right)$ during the entire campaign, which was found to be $0.3 \pm 0.2$. When only considering a period of clean marine air, there is an indication that $\kappa_{\text {org }}$ was also quite hygroscopic, but the measurements preclude an accurate determination of its value.

\section{The Supplement related to this article is available online at doi:10.5194/acp-14-12307-2014-supplement.}

Acknowledgements. The authors thank R. Zhao (University of Toronto), A. Lee (University of Toronto), Emma Mungall (University of Toronto), Robert Christensen (University of Toronto), R. Y.-W. Chang (Dalhousie University), Meng Si (University of British Columbia) and Yuri Jixiao Li (University of Denver) for their help during the campaign and constructive comments regarding this project. NETCARE is funded by NSERC (Canada) through the Climate Change and Atmospheric Research Program. J. A. Huffman acknowledges internal faculty support from the University of Denver. The Marine Boundary Layer site at Ucluelet is located at the coast guard site and we would like to thank the Department of Fisheries and Oceans and all the staff at the site for their help. The MBL site is jointly supported and maintained by Environment Canada, BC Ministry of Environment and MetroVancouver.

Edited by: M. Petters

\section{References}

Aalto, P. and Kulmala, M.: Using a cloud condensation nuclei counter to study CCN properties and concentrations, Boreal Environ. Res., 5, 349-359, 2000.

Albrecht, B. A.: Aerosols, Cloud Microphysics, and Fractional Cloudiness, Science, 245, 1227-1230, 1989.

Allen, G., Coe, H., Clarke, A., Bretherton, C., Wood, R., Abel, S. J., Barrett, P., Brown, P., George, R., Freitag, S., McNaughton, C., Howell, S., Shank, L., Kapustin, V., Brekhovskikh, V., Kleinman, L., Lee, Y.-N., Springston, S., Toniazzo, T., Krejci, R., Fochesatto, J., Shaw, G., Krecl, P., Brooks, B., McMeeking, G., Bower, K. N., Williams, P. I., Crosier, J., Crawford, I., Connolly, P., Allan, J. D., Covert, D., Bandy, A. R., Russell, L. M., Trembath, J., Bart, M., McQuaid, J. B., Wang, J., and Chand, D.: South East Pacific atmospheric composition and variability sampled along $20^{\circ} \mathrm{S}$ during VOCALS-REx, Atmos. Chem. Phys., 11, 5237-5262, doi:10.5194/acp-11-5237-2011, 2011.

Andreae, M. O. and Rosenfeld, D.: Aerosol-cloud-precipitation interactions. Part 1. The nature and sources of cloud-active aerosols, Earth-Sci. Rev., 89, 13-41, doi:10.1016/j.earscirev.2008.03.001, 2008
Ayers, G. P. and Cainey, J. M.: The CLAW hypothesis: a review of the major developments, Environ. Chem., 4, 366-374, doi:10.1071/EN07080, 2007.

Ayers, G. P. and Gras, J. L.: Seasonal relationship between cloud condensation nuclei and aerosol methanesulphonate in marine air, Nature, 353, 834-835, 1991.

Ayers, G. P., Cainey, J. M., Gillett, R. W., Ivey, J. P., Smith, M. H., and Lenton, T.: Atmospheric sulphur and cloud condensation nuclei in marine air in the Southern Hemisphere, Philos. Trans. R. Soc. B Biol. Sci., 352, 203-211, doi:10.1098/rstb.1997.0015, 1997.

Bates, T. S., Calhoun, J. A., and Quinn, P. K.: Variations in the Methanesulfonate to Sulfate Molar Ratio in Marine Aerosol Particles Over the South Pacific Ocean, J. Geophys. Res., 97, 9859-9865, 1992.

Bigg, E. K.: Sources, nature and influence on climate of marine airborne particles, Environ. Chem., 4, 155, doi:10.1071/EN07001, 2007.

Bougiatioti, A., Fountoukis, C., Kalivitis, N., Pandis, S. N., Nenes, A., and Mihalopoulos, N.: Cloud condensation nuclei measurements in the marine boundary layer of the Eastern Mediterranean: $\mathrm{CCN}$ closure and droplet growth kinetics, Atmos. Chem. Phys., 9, 7053-7066, doi:10.5194/acp-9-7053-2009, 2009.

Castebrunet, H., Martinerie, P., Genthon, C., and Cosme, E.: A three-dimensional model study of methanesulphonic acid to non sea salt sulphate ratio at mid and high-southern latitudes, Atmos. Chem. Phys., 9, 9449-9469, doi:10.5194/acp-9-9449-2009, 2009.

Cavalli, F., Facchini, M. C., Decesari, S., Mircea, M., Emblico, L., Fuzzi, S., Ceburnis, D., Yoon, Y. J., O’Dowd, C. D., Pataud, J.-P., and Dell'Acqua, A.: Advances in characterization of size-resolved organic matter in marine aerosol over the North Atlantic, J. Geophys. Res., 109, D24215, doi:10.1029/2004JD005137, 2004.

Chang, R. Y.-W., Slowik, J. G., Shantz, N. C., Vlasenko, A., Liggio, J., Sjostedt, S. J., Leaitch, W. R., and Abbatt, J. P. D.: The hygroscopicity parameter $(\kappa)$ of ambient organic aerosol at a field site subject to biogenic and anthropogenic influences: relationship to degree of aerosol oxidation, Atmos. Chem. Phys., 10, 5047-5064, doi:10.5194/acp-10-5047-2010, 2010.

Charlson, R. J., Schwartz, S. E., Hales, J. M., Cess, R. D., Coakley Jr., J. A., Hansen, J. E., and Hofmann, D. J.: Climate Forcing by Anthropogenic Aerosols, Science, 255, 423-430, 1992.

Chen, L., Wang, J., Gao, Y., Xu, G., Yang, X., Lin, Q., and Zhang, Y.: Latitudinal distributions of atmospheric MSA and MSA/nss$\mathrm{SO}_{4}^{2-}$ ratios in summer over the high latitude regions of the Southern and Northern Hemispheres, J. Geophys. Res., 117, D10306, doi:10.1029/2011JD016559, 2012.

Coggon, M. M., Sorooshian, A., Wang, Z., Metcalf, A. R., Frossard, A. A., Lin, J. J., Craven, J. S., Nenes, A., Jonsson, H. H., Russell, L. M., Flagan, R. C., and Seinfeld, J. H.: Ship impacts on the marine atmosphere: insights into the contribution of shipping emissions to the properties of marine aerosol and clouds, Atmos. Chem. Phys., 12, 8439-8458, doi:10.5194/acp-12-84392012, 2012.

Dusek, U., Frank, G. P., Curtius, J., Drewnick, F., Schneider, J., Kürten, A., Rose, D., Andreae, M. O., Borrmann, S., and Pöschl, U.: Enhanced organic mass fraction and decreased hygroscopicity of cloud condensation nuclei $(\mathrm{CCN})$ during new 
particle formation events, Geophys. Res. Lett., 37, L03804, doi:10.1029/2009GL040930, 2010.

Fuentes, E., Coe, H., Green, D., and McFiggans, G.: On the impacts of phytoplankton-derived organic matter on the properties of the primary marine aerosol - Part 2: Composition, hygroscopicity and cloud condensation activity, Atmos. Chem. Phys., 11, 2585-2602, doi:10.5194/acp-11-2585-2011, 2011.

Good, N., Topping, D. O., Allan, J. D., Flynn, M., Fuentes, E., Irwin, M., Williams, P. I., Coe, H., and McFiggans, G.: Consistency between parameterisations of aerosol hygroscopicity and CCN activity during the RHaMBLe discovery cruise, Atmos. Chem. Phys., 10, 3189-3203, doi:10.5194/acp-10-3189-2010, 2010.

Hartmann, D. L., Ockert-Bell, M. E., and Michelsen, M. L.: The Effects of Cloud Type on Earth's Energy Balance: Global Analysis, J. Climate, 5, 1281-1304, 1992.

Hawkins, L. N., Russell, L. M., Twohy, C. H., and Anderson, J. R.: Uniform particle-droplet partitioning of 18 organic and elemental components measured in and below DYCOMSII stratocumulus clouds, J. Geophys. Res., 113, D14201, doi:10.1029/2007JD009150, 2008.

Hegg, A., Radke, F., and Hobbs, V.: Measurements of Aitken nuclei and cloud condensation nuclei in the marine atmosphere and their relation to the DMS-Cloud-Climate Hypothesis, J. Geophys. Res., 96, 18727-18733, 1991.

Hegg, D. A., Covert, D. S., Jonsson, H. H., and Woods, R.: Differentiating natural and anthropogenic cloud condensation nuclei in the California coastal zone, Tellus B, 61, 669-676, doi:10.1111/j.1600-0889.2009.00435.x, 2009.

Hudson, J. G.: Variability of the relationship between particle size and cloud-nucleating ability, Geophys. Res. Lett., 34, L08801, doi:10.1029/2006GL028850, 2007.

Hudson, J. G., Noble, S., and Jha, V.: On the relative role of sea salt cloud condensation nuclei (CCN), J. Atmos. Chem., 68, 71-88, doi:10.1007/s10874-011-9210-5, 2011.

IPCC: Summary for Policymakers, in Climate Change 2013: The Physical Science Bases, edited by: Stocker, T. F., Quin, D., Plattner, G.-K., Tignor, M., Allen, S. K., Boschung, J., Nauels, A., Xia, Y., Bex, V., and Midgley, P. M.: Cambridge University Press, Cambridge and New York, 2013.

Kanakidou, M., Seinfeld, J. H., Pandis, S. N., Barnes, I., Dentener, F. J., Facchini, M. C., Van Dingenen, R., Ervens, B., Nenes, A., Nielsen, C. J., Swietlicki, E., Putaud, J. P., Balkanski, Y., Fuzzi, S., Horth, J., Moortgat, G. K., Winterhalter, R., Myhre, C. E. L., Tsigaridis, K., Vignati, E., Stephanou, E. G., and Wilson, J.: Organic aerosol and global climate modelling: a review, Atmos. Chem. Phys., 5, 1053-1123, doi:10.5194/acp-5-1053-2005, 2005.

Kerminen, V., Hillamo, R. E., and Wexler, A. S.: Model Simulations on the Variability of Particulate MSA to Non-Sea-Salt Sulfate Ratio in the Marine Environment, J. Atmos. Chem., 30, 345-370, 1998.

Kleinman, L. I., Daum, P. H., Lee, Y.-N., Lewis, E. R., Sedlacek III, A. J., Senum, G. I., Springston, S. R., Wang, J., Hubbe, J., Jayne, J., Min, Q., Yum, S. S., and Allen, G.: Aerosol concentration and size distribution measured below, in, and above cloud from the DOE G-1 during VOCALS-REx, Atmos. Chem. Phys., 12, 207-223, doi:10.5194/acp-12-207-2012, 2012.
Ladino, L. A., Zhou, S., Yakobi-Hancock, J. D., Aljawhary, D., and Abbatt, J. P. D.: Factors controlling the ice nucleating abilities of $\alpha$-pinene SOA particles, J. Geophys. Res.-Atmos., 119, 9041-9051, doi:10.1002/2014JD021578, 2014.

Langley, L., Leaitch, W. R., Lohmann, U., Shantz, N. C., and Worsnop, D. R.: Contributions from DMS and ship emissions to CCN observed over the summertime North Pacific, Atmos. Chem. Phys., 10, 1287-1314, doi:10.5194/acp-10-1287-2010, 2010.

Lathem, T. L., Beyersdorf, A. J., Thornhill, K. L., Winstead, E. L., Cubison, M. J., Hecobian, A., Jimenez, J. L., Weber, R. J., Anderson, B. E. and Nenes, A.: Analysis of CCN activity of Arctic aerosol and Canadian biomass burning during summer 2008, Atmos. Chem. Phys., 13, 2735-2756, doi:10.5194/acp-13-27352013, 2013.

Leck, C. and Bigg, E. K.: Biogenic particles in the surface microlayer and overlaying atmosphere in the central Arctic Ocean during summer, Tellus, 57B, 305-316, 2005a.

Leck, C. and Bigg, E. K.: Source and evolution of the marine aerosol - A new perspective, Geophys. Res. Lett., 32, L19803, doi:10.1029/2005GL023651, 2005b.

Lohmann, U. and Leck, C.: Importance of submicron surface-active organic aerosols for pristine Arctic clouds, Tellus, 57B, 261-268, 2005.

Martin, M., Chang, R. Y.-W., Sierau, B., Sjogren, S., Swietlicki, E., Abbatt, J. P. D., Leck, C., and Lohmann, U.: Cloud condensation nuclei closure study on summer arctic aerosol, Atmos. Chem. Phys., 11, 11335-11350, doi:10.5194/acp-11-11335-2011, 2011.

Matsumoto, K., Tanaka, H., Nagao, I., and Ishizaka, Y.: Contribution of particulate sulfate and organic carbon to cloud condensation nuclei in the marine atmosphere, Geophys. Res. Lett., 24, 655-658, doi:10.1029/97GL00541, 1997.

Mei, F., Hayes, P. L., Ortega, A., Taylor, J. W., Allan, J. D., Gilman, J., Kuster, W., de Gouw, J., Jimenez, J. L., and Wang, J.: Droplet activation properties of organic aerosols observed at an urban site during CalNex-LA, J. Geophys. Res.-Atmos., 118, 2903-2917, doi:10.1002/jgrd.50285, 2013a.

Mei, F., Setyan, A., Zhang, Q., and Wang, J.: CCN activity of organic aerosols observed downwind of urban emissions during CARES, Atmos. Chem. Phys., 13, 12155-12169, doi:10.5194/acp-13-12155-2013, 2013 b.

Meng, J. W., Yeung, M. C., Li, Y. J., Lee, B. Y. L., and Chan, C. K.: Size-resolved cloud condensation nuclei $(\mathrm{CCN})$ activity and closure analysis at the HKUST Supersite in Hong Kong, Atmos. Chem. Phys., 14, 10267-10282, doi:10.5194/acp-1410267-2014, 2014.

Moore, M. J. K., Furutani, H., Roberts, G. C., Moffet, R. C., Gilles, M. K., Palenik, B., and Prather, K. A.: Effect of organic compounds on cloud condensation nuclei $(\mathrm{CCN})$ activity of sea spray aerosol produced by bubble bursting, Atmos. Environ., 45, 7462-7469, doi:10.1016/j.atmosenv.2011.04.034, 2011.

Moore, R. H., Cerully, K., Bahreini, R., Brock, C. A., Middlebrook, A. M., and Nenes, A.: Hygroscopicity and composition of California CCN during summer 2010, J. Geophys. Res.-Atmos., 117, D00V12, doi:10.1029/2011JD017352, 2012.

Ng, N. L., Herndon, S. C., Trimborn, A., Canagaratna, M. R., Croteau, P. L., Onasch, T. B., Sueper, D., Worsnop, D. R., Zhang, Q., Sun, Y. L., and Jayne, J. T.: An Aerosol Chemical Speciation Monitor (ACSM) for Routine Monitoring of the Composi- 
tion and Mass Concentrations of Ambient Aerosol, Aerosol Sci. Technol., 45, 780-794, doi:10.1080/02786826.2011.560211, 2011.

Norman, A. L., Barrie, L. A., Sirois, A., Krouse, H. R., Li, S. M., and Sharma, S.: Sources of aerosol sulphate at Alert: Apportionment using stable isotopes, J. Geophys. Res., 104, 11619-11631, 1999.

Novakov, T. and Penner, J. E.: Large contribution of organic aerosols to cloud-condensation-nuclei concentrations, Nature, 365, 823-826, 1993.

O'Dowd, C. D., Smith, M. H., Consterdine, I. E., and Lowe, J. A.: Marine aerosol, sea-salt, and the marine sulphur cycle: a short review, Atmos. Environ., 31, 73-80, doi:10.1016/S13522310(96)00106-9, 1997.

O'Dowd, C. D. O., Facchini, M. C., Cavalli, F., Ceburnis, D., Mircea, M., Decesari, S., Fuzzi, S., Yoon, Y. J., and Putaud, J.: Biogenically driven organic contribution to marine aerosol, Nature, 431, 676-680, doi:10.1038/nature02959, 2004.

Orellana, M. V., Matrai, P. A., Leck, C., Rauschenberg, C. D., and Lee, A. M.: Marine microgels as a source of cloud condensation nuclei in the high Arctic, P. Natl. Acad. Sci. USA, 108, 13612-13617, doi:10.1073/pnas.1102457108, 2011.

Ovadnevaite, J., Ceburnis, D., Martucci, G., Bialek, J., Monahan, C., Rinaldi, M., Facchini, M. C., Berresheim, H., Worsnop, D. R., and O'Dowd, C.: Primary marine organic aerosol: A dichotomy of low hygroscopicity and high CCN activity, Geophys. Res. Lett., 38, 1-5, doi:10.1029/2011GL048869, 2011.

Petters, M. D. and Kreidenweis, S. M.: A single parameter representation of hygroscopic growth and cloud condensation nucleus activity, Atmos. Chem. Phys., 7, 1961-1971, doi:10.5194/acp-71961-2007, 2007.

Petters, M. D. and Kreidenweis, S. M.: A single parameter representation of hygroscopic growth and cloud condensation nucleus activity - Part 3: Including surfactant partitioning, Atmos. Chem. Phys., 13, 1961-1971, doi:10.5194/acp-13-1081-2013, 2013.

Phinney, L., Richard Leaitch, W., Lohmann, U., Boudries, H., Worsnop, D. R., Jayne, J. T., Toom-Sauntry, D., Wadleigh, M., Sharma, S., and Shantz, N.: Characterization of the aerosol over the sub-arctic north east Pacific Ocean, Deep-Sea Res. Pt. II, 53, 2410-2433, doi:10.1016/j.dsr2.2006.05.044, 2006.

Prather, K. A., Bertram, T. H., Grassian, V. H., Deane, G. B., Stokes, M. D., Demott, P. J., Aluwihare, L. I., Palenik, B. P., Azam, F., Seinfeld, J. H., Moffet, R. C., Molina, M. J., Cappa, C. D., Geiger, F. M., Roberts, G. C., Russell, L. M., Ault, A. P., Baltrusaitis, J., Collins, D. B., Corrigan, C. E., Cuadra-Rodriguez, L. A., Ebben, C. J., Forestieri, S. D., Guasco, T. L., Hersey, S. P., Kim, M. J., Lambert, W. F., Modini, R. L., Mui, W., Pedler, B. E., Ruppel, M. J., Ryder, O. S., Schoepp, N. G., Sullivan, R. C., and Zhao, D.: Bringing the ocean into the laboratory to probe the chemical complexity of sea spray aerosol., P. Natl. Acad. Sci. USA, 110, 7550-7555, doi:10.1073/pnas.1300262110, 2013.

Quinn, P. K. and Bates, T. S.: The case against climate regulation via oceanic phytoplankton sulphur emissions, Nature, 480, 51-56, doi:10.1038/nature10580, 2011.

Roberts, G., Mauger, G., Hadley, O., and Ramanathan, V.: North American and Asian aerosols over the eastern Pacific Ocean and their role in regulating cloud condensation nuclei, J. Geophys. Res., 111, D13205, doi:10.1029/2005JD006661, 2006.
Roberts, G. C., Day, D. A., Russell, L. M., Dunlea, E. J., Jimenez, J. L., Tomlinson, J. M., Collins, D. R., Shinozuka, Y., and Clarke, A. D.: Characterization of particle cloud droplet activity and composition in the free troposphere and the boundary layer during INTEX-B, Atmos. Chem. Phys., 10, 6627-6644, doi:10.5194/acp-10-6627-2010, 2010.

Rose, D., Gunthe, S. S., Mikhailov, E., Frank, G. P., Dusek, U., Andreae, M. O., and Pöschl, U.: Calibration and measurement uncertainties of a continuous-flow cloud condensation nuclei counter (DMT-CCNC): CCN activation of ammonium sulfate and sodium chloride aerosol particles in theory and experiment, Atmos. Chem. Phys., 8, 1153-1179, doi:10.5194/acp-8-11532008, 2008.

Savoie, D. L. and Prospero, J. M.: Comparison of oceanic and continental sources of non-sea-salt sulphate over the Pacific Ocean, Nature, 339, 685-687, 1989.

Savoie, D. L., Arimoto, R., Keene, W. C., Prospero, J. M., Duce, R. A., and Galloway, J. N.: Marine biogenic and anthropogenic contributions to non-sea-salt sulfate in the marine boundary layer over the North Atlantic Ocean, J. Geophys. Res., 107, 4356, doi:10.1029/2001JD000970, 2002.

Shantz, N. C., Leaitch, W. R., Phinney, L., Mozurkewich, M., and Toom-Sauntry, D.: The effect of organic compounds on the growth rate of cloud droplets in marine and forest settings, Atmos. Chem. Phys., 8, 5869-5887, doi:10.5194/acp-8-5869-2008, 2008.

Shantz, N. C., Chang, R. Y.-W., Slowik, J. G., Vlasenko, A., Abbatt, J. P. D., and Leaitch, W. R.: Slower CCN growth kinetics of anthropogenic aerosol compared to biogenic aerosol observed at a rural site, Atmos. Chem. Phys., 10, 299-312, doi:10.5194/acp10-299-2010, 2010.

Shinozuka, Y., Clarke, A. D., DeCarlo, P. F., Jimenez, J. L., Dunlea, E. J., Roberts, G. C., Tomlinson, J. M., Collins, D. R., Howell, S. G., Kapustin, V. N., McNaughton, C. S., and Zhou, J.: Aerosol optical properties relevant to regional remote sensing of $\mathrm{CCN}$ activity and links to their organic mass fraction: airborne observations over Central Mexico and the US West Coast during MILAGRO/INTEX-B, Atmos. Chem. Phys., 9, 6727-6742, doi:10.5194/acp-9-6727-2009, 2009.

Sun, J. and Ariya, P.: Atmospheric organic and bio-aerosols as cloud condensation nuclei (CCN): A review, Atmos. Environ., 40, 795-820, doi:10.1016/j.atmosenv.2005.05.052, 2006.

Twomey, S.: Atmospheric aerosols (Developments in atmospheric science), 7th ed., Elsevier Science Ltd, Amsterdam, 1977a.

Twomey, S.: The influence of pollution on the shortwave albedo of clouds, J. Atmos. Sci., 34, 1149-1152, 1977b.

Wang, J., Lee, Y.-N., Daum, P. H., Jayne, J., and Alexander, M. L.: Effects of aerosol organics on cloud condensation nucleus (CCN) concentration and first indirect aerosol effect, Atmos. Chem. Phys., 8, 6325-6339, doi:10.5194/acp-8-6325-2008, 2008.

Warneck, P.: Chemistry of the Natural Atmosphere, edited by: Dmowska, R. and Holton, J. R., Academic Press, London, 1988. 